\title{
Early down-regulation of chorismate mutase 2 gene expression in a sugarcane cultivar tolerant to Xanthomonas albilineans infection
}

\author{
T.M. Rosa-Santos ${ }^{1}$, L.F. Nogueira², T.A. Paz ${ }^{3}$, R.G. da Silva ${ }^{1}$, \\ J.O.L. Silva ${ }^{2}$, S. Creste ${ }^{4,5}$ and S.M. Zingaretti ${ }^{1,2}$ \\ ${ }^{1}$ Universidade Estadual Paulista, Faculdade de Ciências Agrárias e \\ Veterinárias, Jaboticabal, SP, Brasil \\ ${ }^{2}$ Universidade de Ribeirão Preto, Departamento de Biotecnologia, Ribeirão \\ Preto, SP, Brasil \\ ${ }^{3}$ Universidade Estadual Paulista, Instituto de Química, Araraquara, SP, \\ Brasil \\ ${ }^{4}$ Centro de Cana, Instituto Agronômico de Campinas, Campinas, SP, Brasil \\ ${ }^{5}$ Departamento de Genética, Faculdade de Medicina de Ribeirão Preto, \\ Universidade de São Paulo, Ribeirão Preto, SP, Brasil
}

Corresponding author: S.M. Zingaretti

E-mail: szingaretti@unaerp.br

Genet. Mol. Res. 18 (2): gmr18262

Received February 11, 2019

Accepted June 10, 2019

Published June 24, 2019

DOI http://dx.doi.org/10.4238/gmr183262

\begin{abstract}
Xanthomonas albilineans causes leaf scald disease, one of the most economically important diseases of sugarcane. Leaf scald is a systemic and vascular disease that can severely reduce productivity. The best and primary method of leaf scald control is the use of tolerant cultivars. Knowing that cell wall lignification is a plant defense mechanism and that chorismate mutase is relevant in this process, we analyzed the expression pattern of the chorismate mutase 2 (SoCM2) gene in two contrasting sugarcane cultivars by RT-qPCR. A similar pattern of downregulation for the SoCM2 gene was observed in both cultivars; however, after $72 \mathrm{~h}$, the tolerant cultivar (RB867515) showed repression of the SoCM2 gene, while for the susceptible cultivar (SP78-4467), SoCM2 gene downregulation occurred only after $144 \mathrm{~h}$. Here we propose that early
\end{abstract}


repression of the SoCM2 gene is responsible for tolerance to $X$. albilineans infection in the sugarcane cultivar RB867515.

Key words: Biotic stress; Chorismate mutase 2; Cytosolic; Sugarcane

\section{INTRODUCTION}

Sugarcane (Saccharum spp.) an important source of sugar and ethanol has become the third most commodity in the world $(1.4 \mathrm{G})$ and Brazil figures as a major producer $(500 \mathrm{M}$ tons) (FAOSTAT, 2017). The increasing demand for food and reneweable energy has lead to the expansion of sugarcane cultivated areas, as well as productivity (Hoang et al., 2015). However, several factors such as drought, salinity, temperature and pathogenesis can affect productivity (Qin et al., 2011; Safarnejad et al., 2011).

Leaf scald, caused by Xanthomonas albilineans, is one of the most important and persistent sugarcane diseases (Birch, 2001), decreasing productivity and sugar quality (Rott et al., 2000). Xanthomonas albilineans is the only xanthomonad that produces albicidin, a phytotoxin responsible for a white leaf stripe with necrotic zones at leaf margin, rapid wilting and plant death. Albicidin is a DNA gyrase inhibitor that blocks chloroplast DNA replication and differentiation (Legaz et al., 2018). The disease can appear in three distinct forms: chronic, acute and latent. In the acute and chronic forms, the necrotic zones at leaf margins can easily be seen, but they are not seen in the latent form, and the bacteria can easily be spread by mechanical harvesting. The evolution of the latent to acute form of infection is not only based on the bacterial population, but also on abiotic stress and the cultivars in use (Rott et al., 2000; Birch, 2001).

Plants and microorganism interaction involves a complex and integrative system that includes the synthesis of different compounds, such as effector proteins (AvrB, HopPtoD2, AvrXv4 and XopD) (Beth Mudgett, 2005) and phytotoxins (Coronatine) (He et al., 2004) by the bacteria that will allow the establishment of infection. On the other hand, plants also produce compounds to prevent the establishment of bacteria, such as: phytohormones (ethylene, jasmonic acid, and salicylic acid) (Kazan and Lyons, 2014), transmembrane receptors (FLS2) (Gómez-Gómez and Boller, 2002), cell wall lignification (Vance et al., 1980), among others.

In sugarcane, several genes have been identified as involved in defense mechanisms to biotic stress; e.g. $\beta$-1,3-glucanase was identified in Sporisorium scitamineum sugarcane interaction (Su et al., 2013), NBS-LRR genes acting in systemic acquired resistance (SAR) against Colletotrichum falcatum fungal infection (Selvaraj et al., 2014) and glycoproteins that are produced to inhibit the effect of enzymes secreted by $X$. albilineans during invasion (Legaz et al., 2011). Dabbas et al., (2006) selected differently expressed genes, with different biological functions, when comparing two contrasting sugarcane cultivars (33 induced and 67 repressed) and (53 induced and 47 repressed) for the susceptible and tolerant cultivars respectively, evidencing the complexity of the sugarcane response to $X$. albilineans. Among those, an Expressed Sequence Tag (EST) similar to chorismate mutase was induced.

It is known that chorismate mutase (CM) catalyzes the conversion of chorismate to prephenate and this, in turn, will participate in the biosynthesis of the aromatic amino acids phenylalanine and tyrosine, precursors of secondary metabolites such as lignin, alkaloids 
and cinnamic acid (Mobley et al., 1999; Anterola and Lewis, 2002; Tzin and Galili, 2010; Westfall et al., 2014). In Arabidopsis, three chorismate mutase isoforms (CM1, CM2 and CM3) were identified (Woodin et al., 1978); CM1 and CM3 are located in the plastids, while CM2 is found in the cytosol (Eberhard et al., 1996; Mobley et al., 1999).

Knowing that the membrane lignification is one of the main plant defense mechanisms and that chorismate mutase is relevant in this process, we analyzed the expression pattern of the chorismate mutase 2 (SoCM2) gene in two contrasting sugarcane cultivars by RT-qPCR.

\section{MATERIAL AND METHODS}

\section{Biological material}

Inoculation experiments were conducted at IAC (Sugarcane Center of the Agronomic Institute of Campinas, at Ribeirão Preto, Brazil) in a greenhouse using healthy plants derived from disease-free tissue-cultured plantlets of sugarcane cultivars: SP78-4467 (sensitive to $X$. albilineans Cultivar - SXaC) and RB867515 (tolerant to X. albilineans Cultivar - TXaC). Plants were grown in individual pots containing a mixture of soil, sand, pine, and coconut bark substrate at 3:1:1:1 proportion. Twenty-five sugarcane stalks per cultivar were inoculated by the decapitation method using $X$. albilineans strain IACXa11, considered one of the most aggressive $X$. albilineans isolates found in Brazil (Tardiani et al., 2014), as described by Rott et al., (2011) with modifications. Stalks were cut off using sterile scissors just above leaf +2 , and inoculated using $100 \mu \mathrm{L}$ of bacterial suspension calibrated to $1 \times 10^{8} \mathrm{CFU} \mathrm{mL}{ }^{-1}$ in sterile PBS buffer. Control plants were inoculated using $100 \mu \mathrm{L}$ of sterile PBS buffer. Leaf samples from inoculated and control plants were collected at 24, 72, 144, 360, and $720 \mathrm{~h}$ after inoculation, immediately frozen in liquid nitrogen, and stored at $-80^{\circ} \mathrm{C}$ for further processing.

\section{RNA extraction}

Total RNA was extracted from $200 \mathrm{mg}$ of leaf tissue using the Trizol reagent (Invitrogen, USA), following the manufacturer's recommendations. After extraction, total RNA was quantified in NanoPhotometer P360 (Implen, Germany) and its quality was evaluated by denaturing agarose gel electrophoresis.

\section{RT-qPCR}

For the chorismate mutase 2 (SoCM2) gene expression analyses, a quantitative real time polymerase chain reaction (RT-qPCR) was performed. First strand cDNA was synthesized from total RNA using the RevertAid First Strand cDNA Synthesis kit (Thermo Fisher Scientific, USA) according to the manufacturer's recommendations, and the RTqPCR was performed using $20 \mathrm{ng}$ of cDNA, $200 \mathrm{nM}$ of each primer (Table 1), KAPA SYBR Fast qPCR Master Mix Kit (2X) Universal (Kapa Biosystems, USA), and water with final volume of $20 \mu \mathrm{L}$. In RT-qPCR experiments, cDNA concentration was standardized for each sample, dissociation curve analysis was performed to check primer specificity, and teal time PCR was carried out in a Stratagene MX3005P thermocycler, (California, USA). 
Thermal cycling conditions were as follows: $95^{\circ} \mathrm{C}$ for $3 \mathrm{~min}$, followed by 35 cycles of $95^{\circ} \mathrm{C}$ for $15 \mathrm{~s}, 60^{\circ} \mathrm{C}$ for $30 \mathrm{~s}$, and $72^{\circ} \mathrm{C}$ for $30 \mathrm{~s}$. The dissociation curve was constructed based on: $95^{\circ} \mathrm{C}-1 \mathrm{~m} ; 55^{\circ} \mathrm{C}-30 \mathrm{~s}$, and $95^{\circ} \mathrm{C}-30 \mathrm{~s}$.

Table 1. Nucleotide sequence for primers used in RT-qPCR analyses of the sugarcane chorismate mutase 2 (SoCM2) gene from leaves infected and not infected by Xanthomonas albilineans.

\begin{tabular}{lll}
\hline Gene & Sequence & Amplicon (bp) \\
\hline SoCM2 & F: 5' - GCTCCCGTTATTCACTGTTG - 3' & 134 \\
& R: 5'- CGTCTTTGAACTTCACCTCAG - 3' & 104 \\
a-Tub & F: 5' - CCATTGGCAAGGAGATTGTT - 3' & \\
& R: 5' - TCCACCAACTGCATTGAAGA - 3' & 100 \\
GAPDH & F: 5' - CACGGCCACTGGAAGCA - 3' & \\
& R: 5' - TCCTCAGGGTTCCTGATGCC - 3' \\
\hline
\end{tabular}

The mRNAs expression level was quantified after normalization with constitutive genes glyceraldehyde-phosphate dehydrogenase (GAPDH) and alpha-tubulin ( $\alpha$-TUB) (Thiebaut et al., 2012; Silva et al., 2014) used as internal controls. In the RT-qPCR procedure, all time points were analyzed and three biological replicates were examined to ensure reproducibility.

\section{Statistical analysis}

Expression levels were analyzed using the MxPro QPCR Software version 4.10 (Stratagene, California, USA) and the relative expression values were established by the ratio between the expression of the target gene and the control that was considered 1 .

\section{RESULTS AND DISCUSSION}

The RT-qPCR analysis revealed a similar pattern of downregulation for the SoCM2 gene in the two cultivars. Although gene repression was evident for the two cultivars, down regulation was different at two points, 72 and $144 \mathrm{~h}$ after infection. At 24, 360 and $720 \mathrm{~h}$, the SoCM2 gene exhibited no significant differences in expression levels (Figure 1).

After 72h, the tolerant cultivar (RB867515) showed the first signaling in response to infection with repression of the SoCM2 gene expression from 0.926 to 0.565 . In contrast in the susceptible cultivar (SP78-4467), SoCM2 gene down regulation occurred only after 144h (0.809 to 0.278$)$.

As it is already known, the main difference between tolerance and susceptibility of plants may be a result of the timing of the response; the most tolerant plant perceives the pathogens and immediately activates the necessary mechanism to prevent pathogen invasion (Yang et al., 1997). The mechanisms utilized by sugarcane plants, especially cultivar RB867515 (tolerant) were activated faster, controlling the pathogenic effect caused by the bacterium $X$. albilineans. This is reinforced by the result of the SoCM2 gene expression at 144h for the susceptible cultivar, where it reached its maximum repression (Figure 1). Plants of cultivar SP78-4467 remained susceptible to the free action of X. albilineans for six days before their defense mechanisms signaled by SoCM2 were actually activated. In this 
cultivar, the decrease in gene expression is probably related to late molecular recognition of the pathogen by the sugarcane plant.

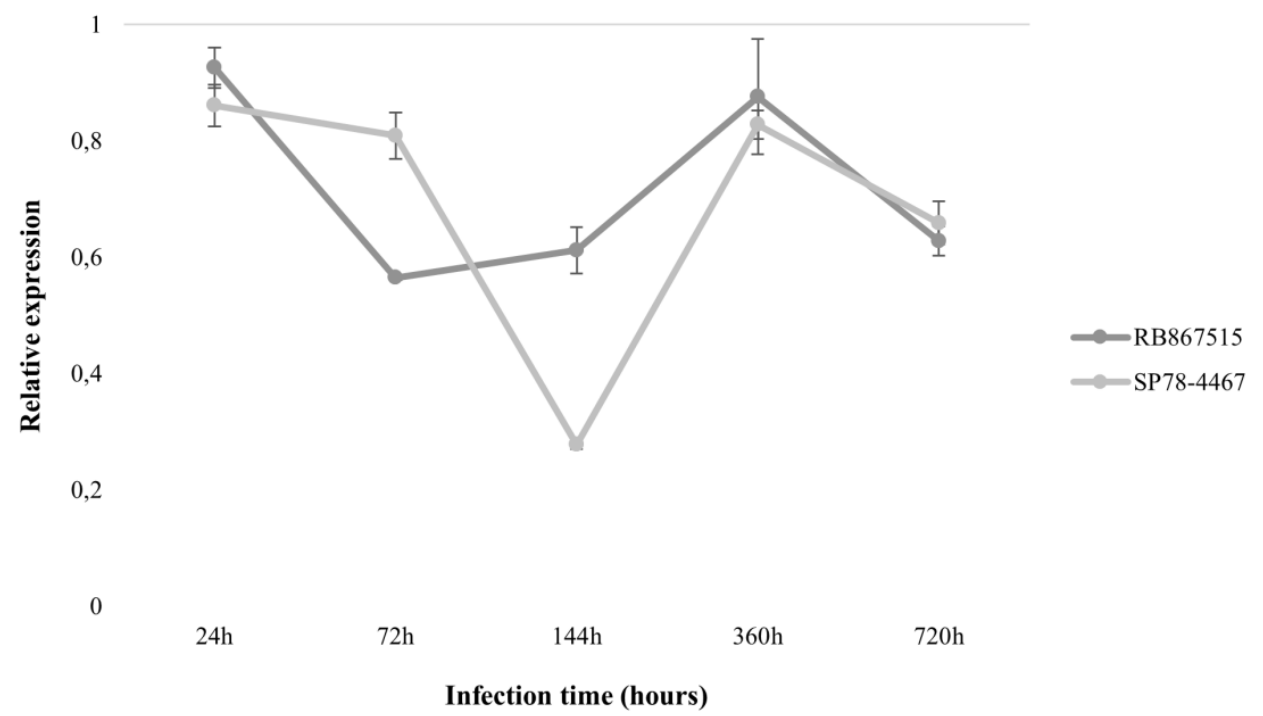

Figure 1. Relative expression profile of the SoCM2 gene in the leaves of cultivars SP78-4467 (susceptible) and RB867515 (tolerant) submitted to infection by Xanthomonas albilineans during the periods of 24, 72, 144, 360 and $720 \mathrm{~h}$, compared to control plants. The relative expression values were established by the ratio between the expression of the target and the control gene, which was considered 1.

Chorismate mutase 2 is a cytosolic enzyme, and the reason for its presence in plants is still unknown (Westfall et al., 2014); however, repression of the CM2 gene has been associated with plant defense mechanisms in Arabidopsis thaliana leaves infected with Fusarium oxysporum (Eberhard et al., 1996) and wounding stress (Mobley et al., 1999).

During $X$. albilineans infection, the cell wall begins to be degraded, and it is worth mentioning that $X$. albilineans has 19 enzymes that degrade the cell wall of the host (Pieretti et al., 2009). As the need for protein in the lignification process increases, SoCM2 is repressed and releases chorismate to be used by CM1 and CM3 (primary metabolism) for the production of aromatic amino acids, e.g. phenylalanine and tyrosine required for the biosynthesis of lignin precursors (Lewis and Yamamoto, 1990). CM2 is modulated by lignin precursors (Woodin et al., 1978); when the lignification process occurs by the induction of CM1 and CM3, the CM2 gene is repressed, as had been reported by Eberhard et al., (1996) CM1 increases in A. thaliana during fungal infection. CM2 has higher catalytic efficiency than the other two isoforms (CM1 and CM3), probably because it is in an environment (cytosol) with low supply of Chorismate, since all mechanisms for amino acid biosynthesis are found in plastids (Westfall et al., 2014).

Our results show that in the RB867515 cultivar, the repression of SoCM2 after $72 \mathrm{~h}$ of infection releasing Chorismate for CM1 and CM3 to produce aromatic amino acids to be used in the lignification process can be responsible for its pathogen tolerance capacity (Figure 2). 


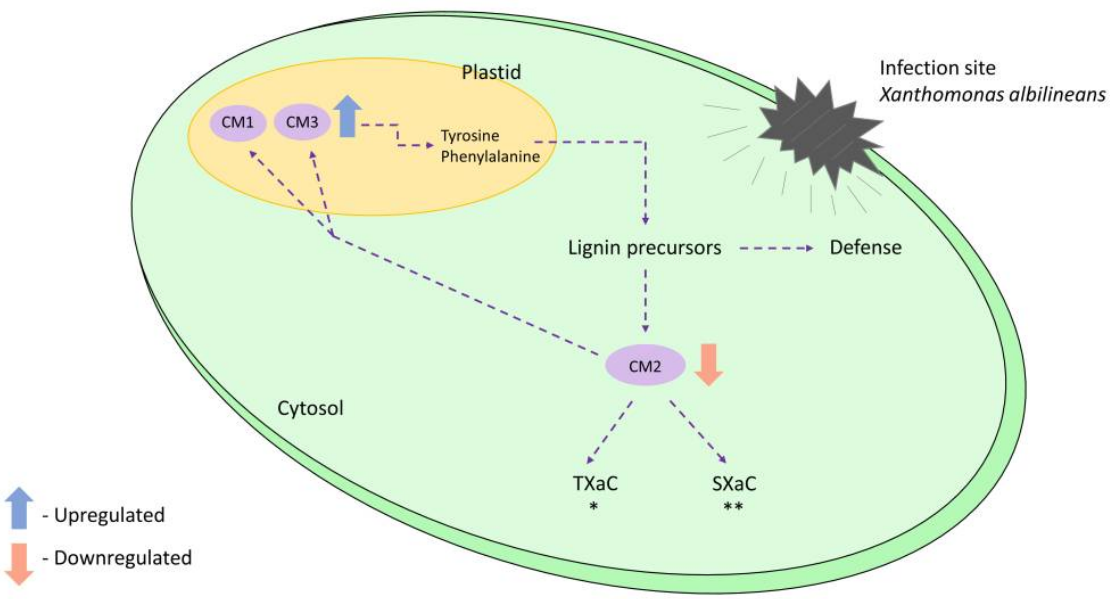

Figure 2. Role of the CM2 sugarcane gene in response to Xanthomonas albilineans infection. During the infection process, the bacterium causes physical damage to the plant, triggering the defense process through lignification. CM1 and CM3 are upregulated (blue arrow), and later the lignification precursors signal to SoCM2 to be downregulated (red arrow), making all the chorismate available in the plastid only for CM1 and CM3. * Early repression in response - ** Later repression in response.

Here we describe how SoCM2 can influence the lignification process in sugarcane. The CM2 decrease will lead to the increase of CM1 and CM3 expression, increasing the production of aromatic amino acids essential in the lignification process.

\section{CONCLUSIONS}

The early repression of SoCM2 gene appears to be responsible for the RB867515 sugarcane cultivar tolerance capacity to Xanthomonas albilineans infection.

\section{ACKNOWLEDGMENTS}

The authors thank FAPESP (Foundation for Research Support of the State of São Paulo) (process number - 2014/19667-8) for the research support, and CNPq (Conselho Nacional de Desenvolvimento Científico e Tecnológico) for the research grant awarded to the first author (process number - 153785/2014-4).

\section{CONFLICTS OF INTEREST}

The authors declare no conflict of interest.

\section{REFERENCES}

Anterola AM and Lewis NG (2002). Trends in lignin modification: a comprehensive analysis of the effects of genetic manipulations/mutations on lignification and vascular integrity. Phytochemistry. 61: 221-294.

Birch RG (2001). Xanthomonas albilineans and the antipathogenesis approach to disease control. Mol. Plant Pathol. 2: $1-11$. 
Dabbas KM, Ferro MIT, Barros NM, Laia ML, et al. (2006). Genes diferencialmente expressos em cana-de-açúcar inoculada com Xanthomonas albilineans, o agente causal da escaldadura da folha. Summa Phytopathol. 32: 328 338.

Eberhard J, Ehrler TT, Epple P, Felix G, et al. (1996). Cytosolic and plastidic chorismate mutase isozymes from Arabidopsis thaliana: molecular characterization and enzymatic properties. Plant J. 10: 815-821.

FAOSTAT (2017). Available at [http://www.fao.org/faostat/en/\#data/QC/visualize]. Accessed April 12, 2019.

Gómez-Gómez L and Boller T (2002). Flagellin perception: a paradigm for innate immunity. Trends Plant Sci. 7: 251256.

He P, Chintamanani S, Chen Z, Zhu L, et al. (2004). Activation of a COI1-dependent pathway in Arabidopsis by Pseudomonas syringae type III effectors and coronatine. Plant J. 37: 589-602.

Hoang NV, Furtado A, Botha FC, Simmons BA, et al. (2015). Potential for genetic improvement of sugarcane as a source of biomass for biofuels. Front. Bioeng. Biotechnol. 3: 1-15.

Kazan K and Lyons R (2014). Intervention of phytohormone pathways by pathogen effectors. Plant Cell. 26: 2285 2309.

Legaz ME, Blanch M, Piñón D, Santiago R, et al. (2011). Sugarcane glycoproteins may act as signals for the production of xanthan in the plant-associated bacterium Xanthomonas albilineans. Plant Signal. Behav. 6: 1132-1139.

Legaz ME, Sánchez-Elordi E, Santiago R, de Armas R, et al. (2018). Metabolic responses of sugarcane plants upon different plant-pathogen interactions. Plant Metab. Regul. Under Environ. Stress. Elsevier. 241-280.

Lewis NG and Yamamoto E (1990). Lignin: occurrence, biogenesis and biodegradation. Annu. Rev. Plant Physiol. Plant Mol. Biol. 41: 455-496.

Mobley EM, Kunkel BN and Keith B (1999). Identification, characterization and comparative analysis of a novel chorismate mutase gene in Arabidopsis thaliana. Gene. 240: 115-123.

Mudgett MB (2005). New insights to the function of phytopathogenic bacterial type III effectors in plants. Annu. Rev. Plant Biol. 56: 509-531.

Pieretti I, Royer M, Barbe V, Carrere S, et al. (2009). The complete genome sequence of Xanthomonas albilineans provides new insights into the reductive genome evolution of the xylem-limited Xanthomonadaceae. BMC Genomics. 10: 616

Qin F, Shinozaki K and Yamaguchi-Shinozaki K (2011). Achievements and challenges in understanding plant abiotic stress responses and tolerance. Plant Cell Physiol. 52: 1569-1582.

Rott P, Bailey RA, Comstock JC, Croft BJ and Saumtally AS (2000). A guide to sugarcane diseases. CIRAD Publication Service, Montpellier.

Rott P, Fleites L, Marlow G, Royer M, et al. (2011). Identification of new candidate pathogenicity factors in the xyleminvading pathogen Xanthomonas albilineans by transposon mutagenesis. Mol. Plant-Microbe Interact. 24: 594 605.

Safarnejad MR, Jouzani GS, Tabatabaie M, Twyman RM and Schillberg S (2011). Antibody-mediated resistance against plant pathogens. Biotechnol. Adv. 29: 961-971.

Selvaraj N, Ramadass A, Amalraj RS, Palaniyandi M, et al. (2014). Molecular profiling of systemic acquired resistance (SAR)-responsive transcripts in sugarcane challenged with Colletotrichum falcatum. Appl. Biochem. Biotechnol. 174: $2839-2850$.

Silva RLO, Silva MD, Ferreira Neto JRC, Nardi CH, et al. (2014). Validation of novel reference genes for reverse transcription quantitative Real-Time PCR in drought-stressed sugarcane. Sci. World J. 2014: 1-12.

Su YC, Xu LP, Xue BT, Wu QB, et al. (2013). Molecular cloning and characterization of two pathogenesis-related $\beta$ 1,3-glucanase genes ScGluA1 and ScGluD1 from sugarcane infected by Sporisorium scitamineum. Plant Cell Rep. 32: $1503-1519$.

Tardiani AC, Perecin D, Peixoto-Junior RF, Sanguino A, et al. (2014). Molecular and pathogenic diversity among brazilian isolates of Xanthomonas albilineans assessed with SSR marker loci. Plant Dis. 98: 540-546.

Thiebaut F, Grativol C, Carnavale-Bottino M, Rojas C, et al. (2012). Computational identification and analysis of novel sugarcane microRNAs. BMC Genomics. 13: 290.

Tzin V and Galili G (2010). The biosynthetic pathways for shikimate and aromatic amino acids in Arabidopsis thaliana. Arab. B. 8: e0132.

Vance CP, Kirk TK and Sherwood RT (1980). Lignification as a mechanism of disease resistance. Annu. Rev. Phytopathol. 18: 259-288.

Westfall CS, Xu A and Jez JM (2014). Structural evolution of differential amino acid effector regulation in plant chorismate mutases. J. Biol. Chem. 289: 28619-28628.

Woodin TS, Nishioka L and Hsu A (1978). Comparison of chorismate mutase isozyme patterns in selected plants. Plant Physiol. 61: 949-952.

Yang Y, Shah J and Klessig DF (1997). Signal perception and transduction in plant defense responses. Genes Dev. 11: $1621-1639$. 